\title{
SOME ASPECTS OF AMERICAN CONSERVATION SCHEMES*
}

\section{Role of Reclamation in Conservation}

\section{By John C. Page, Bureau of Reclamation}

T $\mathrm{HE}$ biggest job for conservationists is to combat the habit of thinking in terms of limitless resources. The destructive results of this habit, seen in our dwindling forests, our abandoned mines, and our gullied fields, have not yet caused sufficient impression to turn us completely away from our foolish optimism as to the future.

The movement towards conservation, begun under Theodore Roosevelt four decades ago with the establishment of the National Forest Service and the Bureau of Reclamation, has received its greatest impetus under President Franklin Roosevelt. Mr. Harold L. Ickes, of the Department of the Interior, defines conservation as 'prudent use'. This is the sense of the word in which the Bureau of Reclamation has tried to carry forward its own particular field of conservation-irrigation in the West. One third of the United States-the West-is arid or semi-arid. Much of this third is desert. Streams periodically drop to tricklets in the dry summer. No agriculture is safe in this West without irrigation, and even irrigation is unsafe without storage reservoirs.

Irrigation in the West is old, was practised before the coming of white men, who took up and improved on Indian methods and thus founded their first settlements. Now twenty million acres have been brought under irrigation, through individual enterprise, cooperative endeavour, and State and Federal aid. Increasing size and complexity of irrigation works have thrust the Federal Government into the position of being the principal agent in the field of water conservation and desert land improvement.

Beneficiaries of this work, carried out by the Bureau of Reclamation, pay its cost. Out of concession to national benefits, the irrigators are not charged interest, but other beneficiaries, such as consumers of electric power, are.

The carefully thought-out conservation work of the Bureau of Reclamation contrasts with earlier methods of developing the West, to which part of our present difficulties are directly traceable. Once western land was regarded as merely a source of revenue. Later, 160 acres was arbitrarily selected as the proper homestead for a family. Still later, it was recognized that irrigation alone would provide the necessary security in most western areas.

With the exception of the Bureau of Reclamation, which plans conservation controls on water and land in advance of their use and development, conservation activity to-day is mainly corrective. The constructive work of the Bureau has resulted in 53,000 new farms, 258 new cities and towns where nearly $1,000,000$ people live.

One fifth of the cost of Federal Reclamation projects has been repaid. The projects turn $10 \mathrm{C}, 000,000$ dollars yearly into the channels of trade. The present programme will ultimately provide 850,000 people with homes.

* From papers presented at the Eighth American Scientific Congress meeting at Washington during May 1940.
The future of reclamation is limited by the West's water supply. Its horizon is placed at $42 \frac{1}{2}$ million acres, about $6 \frac{1}{2}$ per cent of the $700,000,000$ arid and semi-arid acres in the West. Twenty million are already under irrigation, and $2 \frac{1}{2}$ million are in the Bureau's present construction programme, leaving but 20 million available.

\section{Conservation of Forest Resources}

\section{By C. L. Forsling, U.S. Forest Service}

Forests in great variety originally covered $7 \frac{1}{2}$ million square miles, or one half of the land surface of the Western Hemisphere. The area has been reduced to about 6 million square miles since the beginning of the sixteenth century. Growth of population and industries since the middle of the nineteenth century resulted in serious inroads into this rich heritage, especially in the United States, where the deliberate policy of the Government was to transfer ownership of the natural resources into private hands.

The forests of the United States and Canada, owing to their composition and the character of their principal woods, were cut heavily to supply world markets and to meet the needs of growing local populations. Extensive devastation and severe deterioration of the remaining forests resulted. A major problem now is the rehabilitation of these forests to restore them more nearly to their potential continuous productive capacity, which, for the most part, will be a slow process. Meanwhile, demands on the forests of the other American countries will probably increase. Unless steps are taken to prevent it, exploitation of these forests is likely to result in unnecessary destruction or impairment of their productivity, with economic and social effects at least as disastrous as in North America.

The experience of the United States suggests the following essential foundations for a sound policy of forest conservation and use :

(1) Systematic land-use planning to determine, in relation to other forms of land use and social and economic requirements, the amount and character of the available land resource that should be devoted to forestry.

(2) The formulation of policy as to the kind and extent of forest land that should be in public ownership and under public management.

(3) The determination of the means whereby the public may aid in keeping privately owned forest lands productive, and of the degree of public control needed to be exercised over privately owned forest land in order to safeguard the public interest in these resources.

(4) Broad education of people in general and forest owners in particular, as to the value of forests and the basic principles of a forest policy.

(5) A broader knowledge of suitable technique for harvesting and processing forest products, in order to minimize waste, enable efficient operation, and bring the highest sustained income in the long run. 
(6) A broader knowledge of the science and practice of forest management and the underlying sciences, with adequate provision for research in these and related subjects, including better protection from fire, insects, and disease.

(7) Development of uses and markets for all manner of forest products, including research on the properties and utilization of wood and other forest products.

(8) Competent, adequately trained forestry personnel.

(9) A minimum of political interference with forestry personnel and policies.

Co-operation of all American countries is needed in order to advance the science and practice of forestry in the Americas; a Pan-American forestry institute is suggested for this purpose.

\section{National Parks in Conservation}

\section{By Arno B. Cammerer, Director, National Park SERVICE}

The national park idea originated in the New World. In 1870, a party exploring the Yellowstone decided not to try to claim parts of the area for private exploitation but to work for its preservation as a national park to be preserved and enjoyed by the public for all time. Yellowstone, established in 1872, was, therefore, the first national park.

In 1906, the Antiquities Act recognized archæological material on public lands as public property and authorized the President to establish publicly. owned objects of prehistoric, historic, and scientific interest as national monuments, to be preserved intact. In 1916, Congress established the National Park Service to protect the national parks, monuments and similar recreational reservations and to promote their appropriate public use.

In 1933, all national parks, monuments and related historic sites were brought together under the jurisdiction of the National Park Service. In 1935, the Historic Sites Act enunciated the national policy to preserve historic sites and objects for public inspiration and benefit. In 1936, Congress authorized the National Park Service, in co-operation with other Federal agencies and with the States, to conduct a national recreational area study for the purpose of providing a co-ordinated national recreational programme.

The national park system now includes 158 historic and natural areas, totalling $21,515,000$ acres. Recreational utility is the yardstick of good land management. Parks are a form of land use-not a type of scenery. The park type of use is equally applicable to the mountain tops, the great plains, the coastal forests, the deserts, or the seashores. Park standards refer to the type of reservation and not to the type of scenery included in it. In parks we attempt to preserve the land whole. To do so our management must rest upon a sound, scientific basis. Parks are for people to use, but we should not confuse the purposes of the wilderness park with the purposes of the city park. Each has its legitimate purposes and should be developed to achieve those purposes.

How many parks are needed ? The answer cannot be given quantitatively because recreation is a quality of living. There would be more parks if it were not for the vain promises of the multiple use advocates. Multiple use is the theory that lands can be most profitably managed if used in a number of different ways simultaneously. Multiplicity, however, is not and cannot be an objective. Parks and recreational areas may provide multiple use, but multiplicity is merely an incidental phase of good land management. Multiple use as a descriptive term is not objectionable provided it is merely descriptive of that which is an incidental aspect of optimum use. The multiple use theory has been confused with sound land classification. It is believed that the exponents of multiple use really have optimum use in mind. The classification of resources for their best use would result in more adequate recognition of park and recreational lands.

\section{RaNge Conservation}

\section{By R. H. Rutledge, Director, Grazing Service}

In the aftermath of the War of 1914-18, expansion followed by drought, depression, dust storms and shifting populations, America began seriously to take stock of her natural resources. The inventory revealed that a sizable part of our economic and social problems were traceable to a dwindling of range resources. Among other things the evidence led to the conclusion that to ensure the foundation for a desirable standard of living in the range country and in the nation generally there must be an adequate area of forage-producing land and a range conservation programme designed to foster its continued productivity. To secure such a programme Congress passed a number of conservation Acts and placed the conduct and co-ordination of that programme in several Federal agencies. Through the guidance of the Federal Government and the co-operation of States and the citizens range conservation is going forward on a wide front.

The Western range country comprises about half of the total area of the United States. It consists of 11 far-western States and sizable portions of the 6 adjacent plains States. Its gross area of about $1,525,000$ square miles is slightly greater than the total of Bolivia, Chile, Colombia and Ecuador, and its grazable land, containing about $1,137,000$ square miles, is comparable to the area of the Argentine.

Three-fourths of the wool and mohair, half of the lamb and mutton and nearly one third of the beef and veal consumed in the United States is produced in the western range area. Nearly half of the land is in private ownership; the remainder is public land belonging to States, counties and the Federal Government. Collectively these lands comprise the nation's most important watersheds, and within their borders are found practically all of this country's irrigation projects.

Practically all the development and settlement of this vast area has occurred within the past seventyfive years. In a growing nation possessing seemingly unlimited resources there was no guidance, no general plan to assist the citizens in its development. It was inevitable, therefore, that under existing trial and error methods many mistakes occurred. In this area of variable climate, precipitation, altitude and soil texture there is a delicate balance between plant growth and these factors. There is likewise a delicate balance between plant growth and factors of land use.

Livestock numbers are limited to the safe carrying capacity of the land by the issue of licences and permits to resident users of the range. Studies 
are made to determine proper seasons of range use, the class or classes of livestock that can use the range most beneficially, and the feasibility of withdrawing from use certain areas to effect rehabilitation by both artificial and natural means.

The problem of range management involves a study of the relationship between private and public land and the devising of plans to make the use of all the lands compatible with the available resources and the economic structure. Range improvements consisting of water development, re-seeding, erosion control works, trails and other facilities, and the elimination of undesirable elements such as rodents, predators and poisonous plants are included in the programme.

Units to facilitate particular administrative objectives and to localize problems in conformity with community and region welfare assure a broad attack on social and economic, as well as physical fronts. By this means the programme is enabled to outline and develop a type of land use that, in the end, will ensure the stability of the unit involved. In turn, this unit, whether it be a grazing district, a national forest, an Indian reservation, a game range, or any suitable allotment or portion thereof, will reflect the benefits derived on the public welfare generally.

\section{LAND UTILIZATION AND Fish CONSERVATION}

\section{By Elmer Higgins, Bureau of Fisheries}

Land utilization and water utilization are closely related. Water utilization affects aquatic life through changes in habitat. No other group of vertebrates is so delicately adjusted to environment as are fishes. Sudden changes in the nature of environment afford the fishes no opportunity to escape, and death is the only alternative.

Land uses and abuses that have contributed to the diminution of our resources in fresh-water and anadromous fishes, including the effects of agriculture and lumbering, mining operations, petroleum extraction, manufacturing, and the development of urban life and recreational areas are all important. Land restoration practices that do not conserve fish-life include irrigation, power development, canalization of streams, and the draining of sub-marginal lands. Land restoration practices that aid in fish conservation or can be adapted to conservation objectives include erosion control, flood control, pollution abatement, and properly designed water impoundments.

The diversity of interests in land and water utilization demands the development of a co-ordinated conservation programme, particularly with respect to water conservation. The objectives of such a programme may be summed up as follows: The adoption of general principles of water conservation will aid in fishery conservation if the requirements of aquatic life are taken into account when water utilization projects are being planned. In general, the water should be kept on the land, rapid run-off retarded, flood waters stored, erosion prevented, pollution prohibited, canalization of streams minimized, irrigation canals screened, impoundments operated with minimum fluctuation of water-level, dams constructed with outlets at base to improve circulation in reservoirs and provided with fishways where important runs of fishes are obstructed.

\section{SOCIAL STATISTICS OF MERSEYSIDE}

\begin{abstract}
rTHE "New Handbook of Social Statistics relating to Merseyside" prepared by the Statistics Division, Social Science Department, the University of Liverpool (University Press of Liverpool, 1940. ls. net), gives a statistical statement of the position on Merseyside in relation to trade, employment and other social conditions immediately before the outbreak of war. The sections on elementary education and housing have been omitted and rather more material is included relating to the changing state of employment. The first section on the trend of births, deaths and population directs attention to the continuous and steep fall in the birth-rate until the last few years, the level reached in 1938 being about two thirds of that recorded in the 1911-15 quinquennium. The trends of the general death-rate and infant mortality-rate show no evidence of great scope for a further reduction of the general death-rate, and infant mortality is unlikely to decline at the rate experienced in the earlier years of the century. In each of the four boroughs there appears to have been a more or less stable position by 1938 , with even a slight tendency to a natural increase in population.

Figures given for the trade of the Port of Liverpool in comparison with that of London, Hull, Southampton and Manchester show that between 1932 and 1938 import values rose by 30 per cent in both London and Liverpool, while export values increased
\end{abstract}

by 50 per cent in London but only by 24 per cent in Liverpool. Articles wholly or mainly manufactured account for $£ 120$ millions out of $£ 139$ millions exported from Liverpool in 1938, but represent only about one eighth of the goods entering Liverpool. In regard to imports of foods, certain foods touched their lowest point in $1935-37$, afterwards rising to about two thirds of their value in 1927-29, whereas the value of every imported raw material listed was higher in $1935-37$ than in 1930-32, generally receding again slightly in 1938.

Since 1927-29, the number of insured persons on Merseyside has increased from 362,000 to 424,000 , while the number of unemployed rose from 57,000 in 1930 to the 100,000 level in 1935 , declining to 80,000 by the middle of 1939. The tables indicate a decline in shipping and shipbuilding over the last ten years and in transport and distribution since 1932, with expansion in metals and engineering and in general service. Shipping and shipbuilding, transport and distribution, now account for only 41 per cent of the total of insured workers as against one half ten years ago. General service, however, has increased from 12 per cent in 1929 to nearly 18 per cent. Taking all industries, the number of insured-workers employed in 1939 was 12 per cent above the 1929 level on Merseyside and 18 per cent above that level in the country as a whole. With regard to unemployment, 